Check for updates

Cite this: RSC Adv., 2018, 8, 19560

Received 27th February 2018 Accepted 19th May 2018

DOI: $10.1039 / c 8 \mathrm{ra01721b}$

rsc.li/rsc-advances

\section{Insight into mineralizer modified and tailored scorodite crystal characteristics and leachability for arsenic-rich smelter wastewater stabilization $\uparrow$}

\author{
Yonggang Sun, ${ }^{\text {ab }}$ Qi Yao, ${ }^{\text {ab }}$ Xin Zhang, (DD *ab Hongling Yang, ${ }^{\text {ab }} \mathrm{Na} \mathrm{Li}^{\text {ab }}$ \\ Zhongshen Zhang ${ }^{\text {ab }}$ and Zhengping Hao id ab
}

\begin{abstract}
Arsenic-rich non-ferrous smelter wastewater has the potential to cause harm to the environment and human health. The use of mineralizer modified and tailored scorodite crystals, a secondary As-bearing mineral, is considered to be the most promising strategy for arsenic stabilization. In this work, firstly, the mechanisms influencing the scorodite crystal characteristics for arsenic stabilization were investigated, and the results indicated that the scorodite stability was greatly influenced by the scorodite crystal shape and particle size. The crystal shape changes that the scorodite solids undergo during the aging period were observed, from a laminar structure to a polyhedron to a standard octahedral structure, and meanwhile, the As-concentration decreased from $10.2 \mathrm{mg} \mathrm{L}^{-1}$ to $3.7 \mathrm{mg} \mathrm{L}^{-1}$, with the relative particle size value (RPS) increasing from 1.50 to 2.64. Secondly, the addition of a mineralizer to further improve the scorodite crystal stability was investigated. It was meaningful to observe that the lowest Asconcentration of $0.39 \mathrm{mg} \mathrm{L}^{-1}$ could be attained when trace $\mathrm{NaF}$ was employed, and it was of great significance to apply this strategy for the disposal of As and F-containing wastewater due to the electrostatic interaction between scorodite and sodium fluoride. However, the scorodite crystal stability was weakened when other mineralizers $\left(\mathrm{Na}_{2} \mathrm{SiO}_{3} \cdot 9 \mathrm{H}_{2} \mathrm{O}\right.$ and $\left.\mathrm{Al}\left(\mathrm{NO}_{3}\right)_{3} \cdot 9 \mathrm{H}_{2} \mathrm{O}\right)$ were added. This indicated that these mineralizers play different roles in influencing the crystal phase, shapes and sizes of the solid precipitate (mainly scorodite). Finally, the mechanisms of the scorodite crystal evolution and the arsenic leachability characteristics were analyzed. In conclusion, the addition of appropriate mineralizers is a potentially effective strategy for the control of crystal growth, and could be used in the disposal and stabilization of arsenic-rich non-ferrous effluents.
\end{abstract}

\section{Introduction}

Arsenic solidification/stabilization has been and still is a significant and continuous challenge for the non-ferrous extractive metallurgy industry due to the serious effects of arsenic on the environment and human health. ${ }^{1-7}$ Recently, various methods, such as adsorption-desorption, ${ }^{8-11}$ composite membrane permeation, ${ }^{12,13}$ physicochemical encapsulation, ${ }^{\mathbf{1 4 - 1 6}}$ biotechnical stabilization, ${ }^{\mathbf{1 7}, \mathbf{1 8}}$ electro-coagulation, ${ }^{\mathbf{1 9 - 2 1}}$ and chemical precipitation, have been developed and widely applied to treat arsenic-containing effluents. ${ }^{22-24}$ Among these methods, the generation of secondary As-bearing minerals via chemical precipitation is considered the most effective method for the

${ }^{a}$ Department of Environmental Nano-materials, Research Center for Eco-Environmental Sciences, Chinese Academy of Sciences, Beijing 100085, P. R. China. E-mail: zhangxin@rcees.ac.cn; Fax: +86-10-62843096; Tel: +86-10-62843688 ${ }^{b}$ National Engineering Laboratory for VOCs Pollution Control Material \& Technology, University of Chinese Academy of Sciences, Beijing 101408, P. R. China

$\dagger$ Electronic supplementary information (ESI) available. See DOI: 10.1039/c8ra01721b solidification/stabilization of arsenic in mining and non-ferrous smelting processes.

Secondary As-bearing minerals are usually one of several types of chemical system, namely, As- $\mathrm{O}^{25,26} \mathrm{As}-\mathrm{Ca}-\mathrm{O},{ }^{6,27,28} \mathrm{Fe}-$ As-O,$^{29,30}$ and As-Ca-Fe systems. ${ }^{30,31}$ As-O systems (mainly claudetite and arsenolite) are relatively common secondary minerals formed by the oxidation of arsenic. However, these systems are unstable under ambient conditions and dissolve easily in water and acids. ${ }^{232}$ Similarly, As-Ca-O systems, primarily including pharmacolite $\left[\mathrm{Ca}\left(\mathrm{HAsO}_{4}\right) \cdot 2 \mathrm{H}_{2} \mathrm{O}\right]$ and haidingerite $\left[\mathrm{Ca}\left(\mathrm{AsO}_{3} \mathrm{OH}\right) \cdot \mathrm{H}_{2} \mathrm{O}\right]$, have high solubility ranging from $2 \mathrm{~g} \mathrm{~L}^{-1}$ to $4 \mathrm{~g} \mathrm{~L}^{-1}$ in natural-water systems. ${ }^{6,33} \mathrm{As}-\mathrm{Ca}-\mathrm{Fe}$ systems, mainly including arseniosiderite and yukonite, occur in almost neutral environments. The solubility of arseniosiderite and yukonite were reported by Krause and $\operatorname{Ettel}^{30,31}$ to be the following: $6.7 \mathrm{mg} \mathrm{L^{-1 }}$ at pH 6.8 and $25{ }^{\circ} \mathrm{C}$ for arseniosiderite and $6.3 \mathrm{mg} \mathrm{L}^{-1}$ at $\mathrm{pH} 6.15$ and $25^{\circ} \mathrm{C}$ for yukonite, which exceed the EPA-TCLP test limit. ${ }^{34}$ To some degree, yukonite can also be considered in the process of arsenic stabilization/solidification due to its low arsenic release at relevant industrial $\mathrm{pH}$ values under tailings conditions. ${ }^{35}$ Generally, Fe-As-O systems exhibit 
lower arsenic release than that of As-Ca-Fe-O systems. The FeAs-O system mainly includes scorodite and BFAS. The production of scorodite has been proposed as a potentially good method for the fixation of arsenic due to the unique properties of the mineral, including low solubility, high arsenic content, and controlled precipitation. ${ }^{36}$ Scorodite, a crystalline ferric arsenate, is a naturally occurring secondary supergene mineral with the chemical formula $\mathrm{FeAsO}_{4} \cdot 2 \mathrm{H}_{2} \mathrm{O}$. There is currently a large focus on the use of scorodite for the immobilization and disposal of arsenic due to the mineral's high removal efficiency and low solubility. ${ }^{7}$

However, it is significant to observe that while there have been many efforts devoted to the investigation of the solubility and dissolution process for the $\mathrm{Fe}-\mathrm{As}-\mathrm{O}$ system, ${ }^{37,38}$ the previous studies present remarkably different results, some of which even oppose each other to some extent. For example, Langmuir ${ }^{39}$ obtained a leached As-concentration of $\sim 90 \mathrm{mg} \mathrm{L}^{-1}$ at $\mathrm{pH}=1$. However, Harvey ${ }^{\mathbf{4 0}}$ reported minimum arsenic solubility values of $\sim 19 \mathrm{mg} \mathrm{L}^{-1}$ under similar conditions. This was mainly caused by the difference in crystal growth processes. However, little was known with certainty about the correlation between crystal behavior and arsenic leaching characteristics.

The objective of this work was to investigate the synthesis and crystal growth process of scorodite for arsenic fixation. Specifically, the leaching characteristics of arsenic were analyzed under various synthesis conditions and crystal growth stages, and then the mineralizer modified and tailored scorodite crystal characteristics and leachability for arsenic-rich smelter wastewater were intensively investigated. Finally, the mechanisms of scorodite crystal evolution were analyzed. It is expected that this current work can provide a practical guide for arsenic stabilization.

\section{Materials and methods}

\subsection{Scorodite synthesis}

An aqueous solution of arsenic, derived from the purification and concentration of effluent from a copper smelter, was used for our experiments. The total composition of the solution used from the copper smelter is as follows: As $34 \mathrm{~g} \mathrm{~L}^{-1}, \mathrm{Zn} 0.2 \mathrm{~g} \mathrm{~L}^{-1}$, and $\mathrm{Cd} 0.8 \mathrm{~g} \mathrm{~L}^{-1}$. Scorodite precipitates were synthesized at $\mathrm{pH}$ 2.5 with different Fe/As mole ratios $(1.5,2.0$, and 3.0$)$ and reaction times $(1 \mathrm{~h}, 3 \mathrm{~h}$, and $5 \mathrm{~h})$ at $95{ }^{\circ} \mathrm{C}$, by the oxidation of ferrous ions in an aqueous arsenic solution. The ambient air was used as an oxidizing agent. Additionally, a control group consisting of a ferric sulfate solution was mixed with an arsenic solution at an Fe/As mole ratio of 2.0 under the same conditions. The washing steps (pre-treatment) of the solids before they underwent TCLP tests were as follows. Firstly, the scorodite reaction liquid after co-precipitation underwent ultrasound irradiation at room temperature for $30 \mathrm{~min}$ to remove any of the adsorbed amorphous material, and then the solids were recovered via filtration. It was then purified through repeated washing (two times) with ultrapure water and centrifuged. Next, the leaching concentrations for Fe, As, and other mineralization elements for solid precipitates in the last filtrate were detected, and finally, it was dried at $60{ }^{\circ} \mathrm{C}$ for $12 \mathrm{~h}$. The filtrate and final solids were collected and analyzed using ICP-OES, the fluoride $\left(\mathrm{F}^{-}\right)$concentration was measured using an Ion Chromatograph (Aquion), and the surface compositions were determined using FESEM-EDS. The following sections detail each of these techniques. The repeatability of the experiment was investigated and the average values were used in the text.

\subsection{Aging process}

After the scorodite was synthesized, the effects of aging time and temperature on the leachability were examined using static aging at low temperatures $\left(35^{\circ} \mathrm{C}, 55{ }^{\circ} \mathrm{C}\right.$, and $\left.75{ }^{\circ} \mathrm{C}\right)$ and with hydrothermal processes for high temperature $\left(100{ }^{\circ} \mathrm{C}\right.$ and 120 ${ }^{\circ} \mathrm{C}$ ). After $25 \mathrm{~h}$ of aging, each solid was filtered and washed with deionized water, dried, and then subjected to leaching toxicity tests.

\subsection{Chemical mineralization process}

Hydrothermal mineralization experiments were conducted using $\mathrm{Na}_{2} \mathrm{SiO}_{3} \cdot 9 \mathrm{H}_{2} \mathrm{O}$-modified, $\mathrm{Al}\left(\mathrm{NO}_{3}\right)_{3} \cdot 9 \mathrm{H}_{2} \mathrm{O}$-modified, and NaF-modified as mineralizers at different temperatures $\left(120^{\circ} \mathrm{C}\right.$, $150{ }^{\circ} \mathrm{C}$, and $180{ }^{\circ} \mathrm{C}$ ) for $25 \mathrm{~h}$, ensuring that the final concentration of the mineralizers was $0.02 \mathrm{M}$. After the hydrothermal treatment, the reaction kettle was allowed to cool to atmospheric conditions. The reaction product was then filtered and washed with deionized water and finally dried.

\subsection{Characterization and analysis}

All sample compositions were analyzed using inductively coupled plasma optical emission spectroscopy (ICP-OES, Prodigy) and/or inductively coupled plasma mass spectrometry (ICP-MS, NeXION 300X), which was used to determine the concentrations of arsenic in the solution samples as well as for the determination of the solid-product composition after digestion at $40{ }^{\circ} \mathrm{C}$ for $12 \mathrm{~h}$ in $5 \mathrm{M} \mathrm{HCl}$ solution. Additionally, the fluoride $\left(\mathrm{F}^{-}\right)$concentration was measured using an Ion Chromatograph (IC, Aquion).

A field emission scanning electron microscope equipped with an energy dispersive spectrometer (FESEM-EDS, SU-8020) was used for the observation of particle morphology, surface elemental compositions, and phase distribution.

A transmission electron microscope (TEM, JEM-2100) was used to observe the microstructure of the reaction product. $\mathrm{X}$ ray diffraction (XRD, X'Pert PRO MPD) was used to identify the different crystalline phases in the samples. It was performed on a powder diffractometer using a copper target (K $\alpha$ radiation $\lambda=1.5418 \AA$ ) in a $2 \theta$ range of $5-90^{\circ}$ with a scanning rate of $8^{\circ} \mathrm{min}^{-1}$ at $40 \mathrm{kV}$ and $40 \mathrm{~mA}$.

The particle size distributions were determined using a Mastersizer 2000 analyzer. A Fourier transform infrared spectrometer (FT-IR, Nicolet 8700) was used to analyze the change of functional groups and bonding.

\subsection{Toxicity Characteristics Leaching Procedure test}

The US Environmental Protection Agency's Toxicity Characteristics Leaching Procedure test (EPA-TCLP), ${ }^{34}$ which is the most 
widely used test procedure, was also used on some of the solids. The solid wastes were extracted for $18 \pm 2 \mathrm{~h}$ with an extraction of a buffered acetic acid solution at $\mathrm{pH}=4.93 \pm 0.05$ and a solid-to-liquid ratio of $1: 20(\mathrm{w} / \mathrm{v})$. Once the test was over, the supernatant was separated from the solid phase by filtering through a $0.22 \mu \mathrm{m}$ fiber filter and subsequently diluted to a proper concentration range before the ICP-OES or ICP-MS analysis.

\section{Results and discussion}

\subsection{Scorodite synthesis and crystal growth process}

3.1.1 Effect of iron sources and $\mathrm{Fe} / \mathrm{As}$ molar ratios. The effects of different iron sources $\left(\mathrm{Fe}^{2+}\right.$ or $\left.\mathrm{Fe}^{3+}\right)$ and $\mathrm{Fe} / \mathrm{As}$ molar ratios $(1.5,2.0$ and 3.0) on the arsenic removal rate and As or Feleachability were investigated. As shown in Fig. 1, the leaching As-concentration and removal rate showed a consistent variation trend with the rise of Fe/As ratio, regardless of the iron source. The leached As-concentration initially decreased with the increase of the Fe/As ratio from 1.5 to 2. It then remained consistent when the Fe/As ratio was further increased to 3. A similar variation regime was observed for the removal rate of arsenic in Fig. 1c. Additionally, a higher As-leachability than Feleachability was observed at various Fe/As molar ratios, which means that the incongruent dissolution of scorodite can take place in the systems. Moreover, the concentration of arsenic leaching when $\mathrm{Fe}^{3+}$ was the iron source $\left(>70 \mathrm{mg} \mathrm{L}^{-1}\right)$ was remarkably higher than when $\mathrm{Fe}^{2+}$ was the iron source $\left(<15 \mathrm{mg} \mathrm{L}^{-1}\right)$. The poor crystallinity of ferric arsenate was one of the main causes of these results, but the presence of other factors such as lack of washing procedures for amorphous phases requires further analysis. Nevertheless, it is significant to observe that the removal rate of As with $\mathrm{Fe}^{3+}$ as an iron source was slightly higher than that with $\mathrm{Fe}^{2+}$ as an iron source.
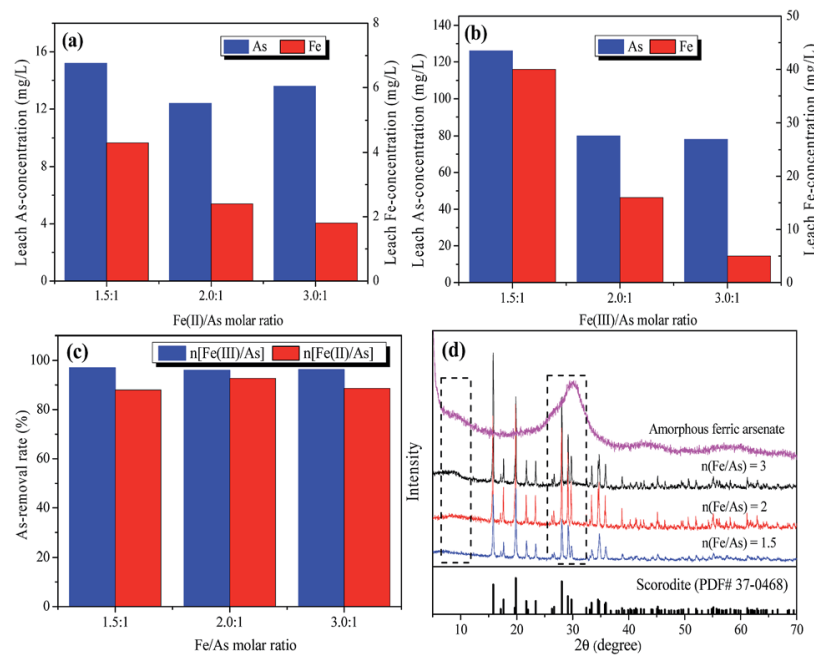

Fig. 1 Effect of the Fe/As molar ratio and the iron sources (a) Fe(॥)/As and (b) Fe(III)/As on leaching As-concentration and Fe-concentration, (c) the As-removal rate for solid samples obtained at $\mathrm{pH} 2.5$ at $95^{\circ} \mathrm{C}$ for $5 \mathrm{~h}$, and (d) XRD spectra of scorodite samples obtained at various Fe/As molar ratios, $\mathrm{pH} 2.5$, and $95^{\circ} \mathrm{C}$ for $5 \mathrm{~h}$.
Furthermore, as shown in Fig. 1d, XRD patterns were employed to explore the existence of the Fe-As form with different iron sources and Fe/As molar ratios. It is worth noting that Fe-As mainly existed in the form of well-crystalline scorodite (PDF No. 37-0468) with $\mathrm{Fe}^{2+}$ as the iron source. Meanwhile, amorphous ferric arsenate was the main phase that existed with $\mathrm{Fe}^{3+}$ as the iron source. Therefore, it is logical to assume that the decrease in arsenic leaching when $\mathrm{Fe}^{2+}$ was the iron source was due mainly to the formation of stable scorodite, and the easily formed amorphous ferric arsenate was responsible for the higher As-removal rate. However, some amorphous phase was produced with the increase of the Fe/As ratio from 1.5 to 3 , as it was observed that there are diffraction peaks between 8-12 and 25-35 $2 \theta$ under the crystalline pattern, thus indicating that a mixed crystal phase had formed for the arseniccontaining solids.

3.1.2 Effect of the reaction time on arsenic leachability and crystal growth. Fig. 2 shows the arsenic and iron leaching concentration, and the removal rate as a function of reaction time for the experiments performed using EPA-TCLP methods. The test sample was obtained at an Fe/As molar ratio of 2, a $\mathrm{pH}$ of 2.5 , and $95{ }^{\circ} \mathrm{C}$. It can be clearly seen that the leached Asconcentration decreased gradually from $33.1 \mathrm{mg} \mathrm{L}^{-1}$ to $12.4 \mathrm{mg} \mathrm{L}^{-1}$ with the increase in reaction time from $1 \mathrm{~h}$ to $5 \mathrm{~h}$. Simultaneously, the Fe concentration also decreased with the increase of reaction time, and the As removal rate increased from $80 \mathrm{wt} \%$ to $91 \mathrm{wt} \%$ as the reaction proceeded. This is attributed to the formation of well-crystalline scorodite, which was proven by the XRD patterns and FESEM images.

Fig. 3 shows FESEM and TEM images of the produced scorodite after various reaction times. The detailed results indicated that the crystal shape changes that the scorodite solids undergo are from a laminar structure to a polyhedron to a standard octahedral structure with the different reaction times, and the individual scorodite particles are about $\sim 2 \mu \mathrm{m}$ in diameter. It can be concluded that the scorodite morphology can greatly affect the As-leaching behavior. Furthermore, the TEM patterns were further studied to explain the growth process. It was revealed (Fig. 3d-f) that the scorodite existed as single crystals with preferential growth along the [001] direction, and eventually, it displayed the octahedral shape with planes composed primarily of (111) planes in the orthorhombic structure. This standard crystal structure was stable under
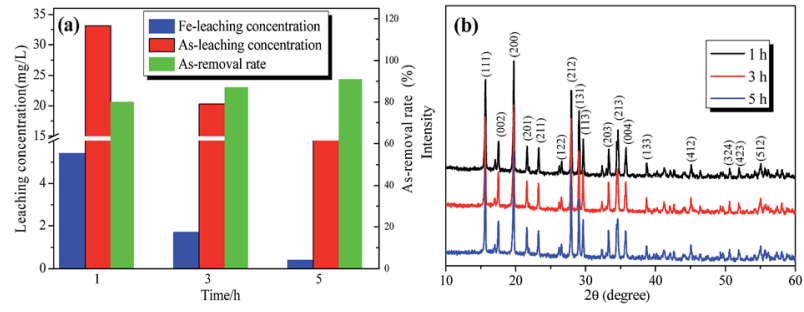

Fig. 2 Effect of the reaction time on (a) As or Fe-leachability and Asremoval rate, (b) the XRD pattern of the scorodite samples, which was obtained at an Fe/As molar ratio of 2 , a pH of 2.5 , and $95^{\circ} \mathrm{C}$. 


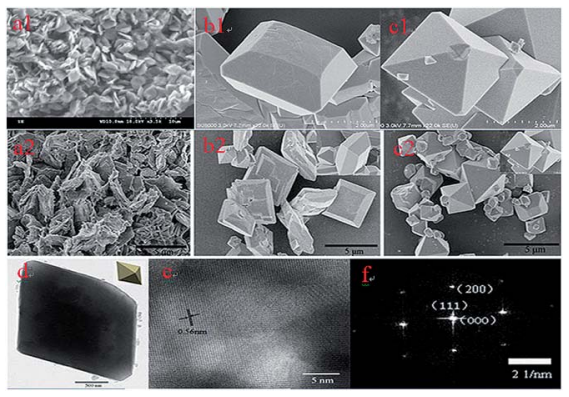

Fig. 3 SEM and TEM images of the synthesized scorodite at various reaction times: (a1 and a2) $1 \mathrm{~h}$, (b1 and b2) $3 \mathrm{~h}$, and (c1 and c2) $5 \mathrm{~h}$. (d, e and f) TEM images and electron diffraction pattern.

a thermodynamic equilibrium state, which was suitable for the solidification/stabilization of arsenic.

\subsection{Effect of aging temperature on As-leachability}

The effect of aging temperature on the leached As-concentration is presented in Fig. 4. It can be clearly seen that the leached Asconcentration decreased gradually from $10.2 \mathrm{mg} \mathrm{L}^{-1}$ to $3.7 \mathrm{mg} \mathrm{L}^{-1}$ when the aging temperature increased from $35^{\circ} \mathrm{C}$ to $120^{\circ} \mathrm{C}$, and the Fe-leachability showed a comparable variation trend. Similarly, XRD patterns and SEM images for the scorodite at different aging temperature intervals are shown in Fig. 5 and 6; consistent well-crystalline diffraction peaks and an octahedral morphology of the scorodite particles were observed when the temperature increased from $35^{\circ} \mathrm{C}$ to $120^{\circ} \mathrm{C}$, indicating that aging temperature had almost no influence on the scorodite crystal shape. Additionally, the particle size distribution of scorodite at various temperatures is displayed in Fig. 7. As shown in Fig. 7a, the neat curves were dominated mainly by two sizes of particles, i.e., small fine particles $(\sim 0.2 \mu \mathrm{m})$ and large particles $(\sim 10 \mu \mathrm{m})$. Furthermore, the effects of particle size on As-leaching concentrations were explored. It was significant to observe that the As-leachability had a linear positive correlation with small particles (Fig. 7b) and a linear negative correlation with large particles (Fig. 7c). In particular, the arsenic leachability increased with the increase of small particle content and

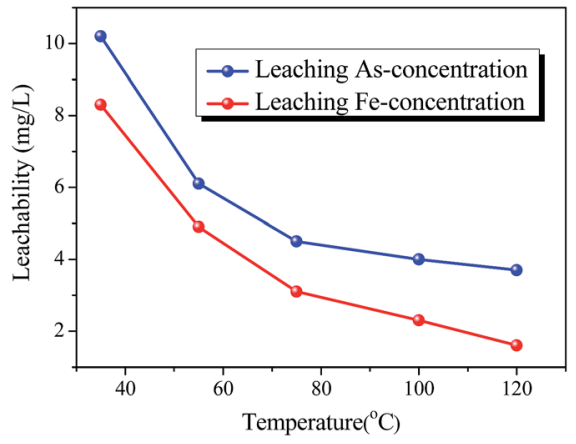

Fig. 4 The effect of aging temperature on leaching As-concentration (EPA-TCLP methods) for solid samples. The samples were obtained at $95^{\circ} \mathrm{C}$ with an Fe/As molar ratio of 2 , and $\mathrm{pH} 2.5$.

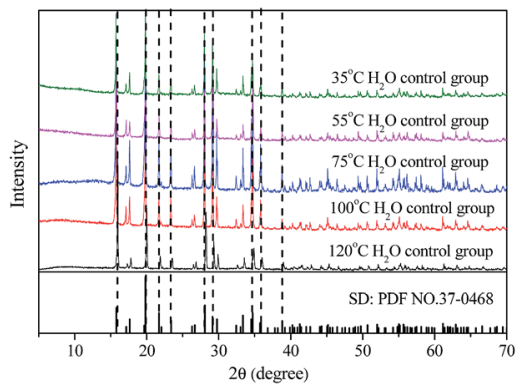

Fig. 5 XRD patterns of samples at various temperatures $\left(35^{\circ} \mathrm{C}, 55^{\circ} \mathrm{C}\right.$, $75^{\circ} \mathrm{C}, 100^{\circ} \mathrm{C}$, and $120^{\circ} \mathrm{C}$ ) with an Fe/As molar ratio of 2 , and $\mathrm{pH} 2.5$ for $25 \mathrm{~h}$.

decreased with the large particle content. Additionally, a concept of "relative particle size value (RPS)" was proposed to further research the effect of aging temperature on Asleachability and particle size. This concept refers to the sum volume fraction of large particle size distribution $(1-100 \mu \mathrm{m})$ divided by the sum volume fraction of small particle size distribution (0.1-0.3 $\mu \mathrm{m})$. As shown in Fig. 7d, the leaching Asconcentration significantly decreased with the increase of RPS, as it decreased from $10.2 \mathrm{mg} \mathrm{L}^{-1}$ to $3.7 \mathrm{mg} \mathrm{L}^{-1}$ when the RPS increased from 1.50 to 2.64 . Similarly, a relatively high aging temperature led to an increase of RPS and then reduced the leaching As-concentration. As a larger particle size was preferred due to a low surface-to-volume ratio making scorodite more stable in the reaction system, the results align with those previously reported by Kitamura ${ }^{41}$ and Fujita. ${ }^{42}$ Therefore, a higher aging temperature is beneficial for improving scorodite stability.

\subsection{Effect of mineralizers on leaching As characteristics}

The arsenic leachability was strongly dependent on the scorodite crystal shapes as well as the particle size. The wellcrystalline shapes and the particle size can be improved by prolonging the reaction time and increasing the aging temperature, respectively. Therefore, a new strategy was tentatively applied in the present work, in order to further improve the As-leachability. Namely, three kinds of mineralizer

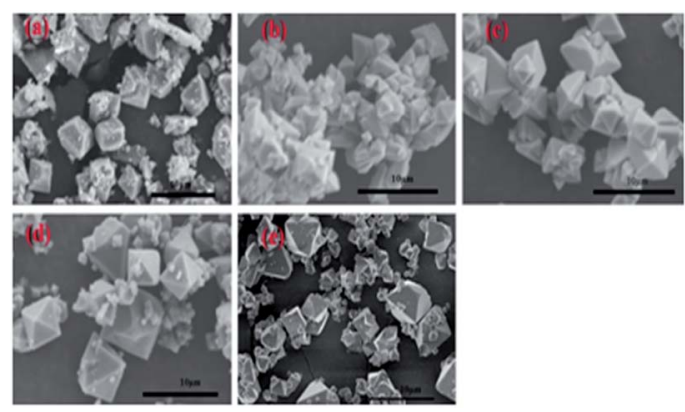

Fig. 6 SEM images of scorodite at system temperatures of (a) $35^{\circ} \mathrm{C}$, (b) $55^{\circ} \mathrm{C}$, (c) $75^{\circ} \mathrm{C}$, (d) $100{ }^{\circ} \mathrm{C}$, and (e) $120^{\circ} \mathrm{C}$ with an Fe/As molar ratio of 2 , and $\mathrm{pH} 2.5$ for $25 \mathrm{~h}$. 

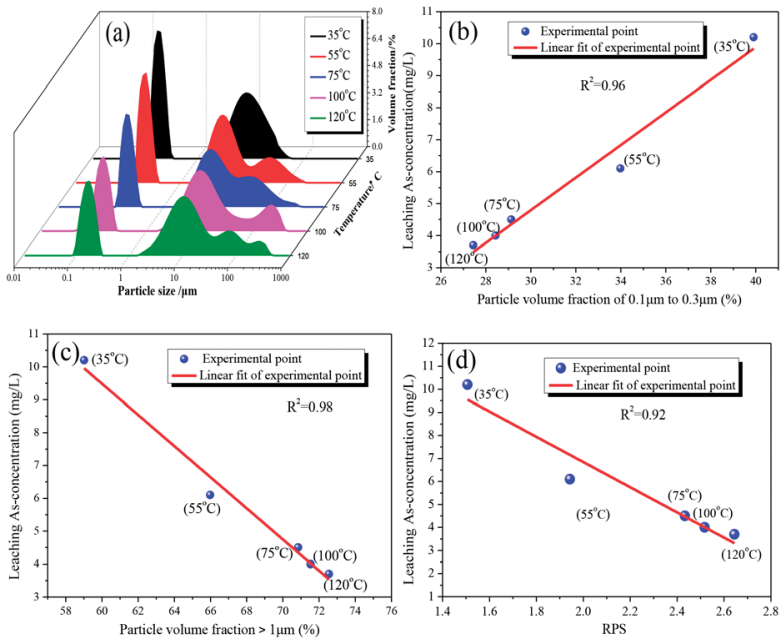

Fig. 7 The particle distribution curves (a), the As-leachability correlation with small particle (b), with large particle (c), and with the arsenic leachability correlation with RPS (d) at different temperatures $\left(35^{\circ} \mathrm{C}, 55\right.$ ${ }^{\circ} \mathrm{C}, 75^{\circ} \mathrm{C}, 100{ }^{\circ} \mathrm{C}$, and $120^{\circ} \mathrm{C}$ ) at Fe/As molar ratio of 2 , and $\mathrm{pH} 2.5$ for $25 \mathrm{~h}$.

$\left(\mathrm{Na}_{2} \mathrm{SiO}_{3} \cdot 9 \mathrm{H}_{2} \mathrm{O}, \mathrm{Al}\left(\mathrm{NO}_{3}\right)_{3} \cdot 9 \mathrm{H}_{2} \mathrm{O}\right.$, and $\left.\mathrm{NaF}\right)$ were added during the scorodite forming process, and the aging temperature was further raised to a higher temperature $\left(120^{\circ} \mathrm{C}, 150{ }^{\circ} \mathrm{C}\right.$, and 180 $\left.{ }^{\circ} \mathrm{C}\right)$.

As shown in Fig. 8, the stability test indicated that the addition of each of the three mineralizers presented rather a different variation effect on the arsenic leachability. Significantly, the addition of NaF induced a considerable decrease in the arsenic leachability, which was initially decreased and then increased slightly when the aging temperature was increased from $120{ }^{\circ} \mathrm{C}$ to $180{ }^{\circ} \mathrm{C}$. It was worth noting that the lowest leaching As-concentration of $0.39 \mathrm{mg} \mathrm{L}^{-1}$ can be achieved at $150{ }^{\circ} \mathrm{C}$, which was far lower than the EPA-TCLP test limit of $5 \mathrm{mg} \mathrm{L}^{-1}$ and values reported in literature (seen in Table $\mathrm{S} 1 \dagger$ ). In contrast with the results with $\mathrm{NaF}$, when $\mathrm{Al}\left(\mathrm{NO}_{3}\right)_{3} \cdot 9 \mathrm{H}_{2} \mathrm{O}$ was adopted as a mineralizer, the leaching As-concentration gradually increased from 1.22 to $3.10 \mathrm{mg} \mathrm{L}^{-1}$ with the increase in aging temperature from $120^{\circ} \mathrm{C}$ to $180^{\circ} \mathrm{C}$. However, the opposite result was observed when $\mathrm{Na}_{2} \mathrm{SiO}_{3} \cdot 9 \mathrm{H}_{2} \mathrm{O}$ was adopted as

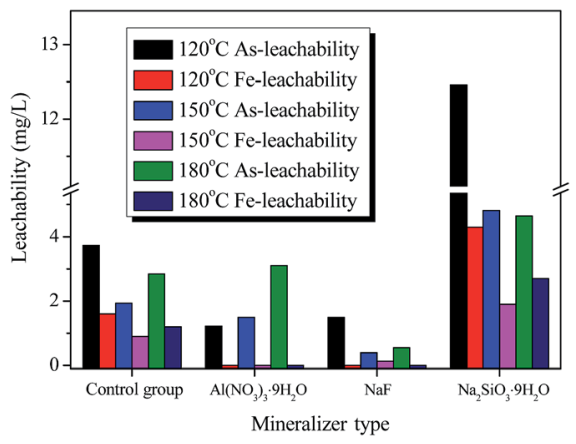

Fig. 8 The As-leachability with various mineralizers $\left(\mathrm{Na}_{2} \mathrm{SiO}_{3} \cdot 9 \mathrm{H}_{2} \mathrm{O}\right.$, $\mathrm{Al}\left(\mathrm{NO}_{3}\right)_{3} \cdot 9 \mathrm{H}_{2} \mathrm{O}$, and $\left.\mathrm{NaF}\right)$ and at various temperatures $\left(120^{\circ} \mathrm{C}, 150^{\circ} \mathrm{C}\right.$, and $180{ }^{\circ} \mathrm{C}$ ) for $25 \mathrm{~h}$. a mineralizer, as the leaching As-concentration was substantially higher than that of the control group at each point. In particular, the use of $\mathrm{Na}_{2} \mathrm{SiO}_{3} \cdot 9 \mathrm{H}_{2} \mathrm{O}$ as a mineralizer accelerated the release of arsenic from scorodite instead of preventing it, and these results are different to those reported by $\mathrm{Nazari}^{7}$ and Twidwell, ${ }^{43}$ so further research is urgently needed in followup experiments. Additionally, the leachability and composition of solid precipitates with various mineralizers $\left(\mathrm{Na}_{2} \mathrm{SiO}_{3} \cdot 9 \mathrm{H}_{2} \mathrm{O}\right.$, $\left.\mathrm{Al}\left(\mathrm{NO}_{3}\right)_{3} \cdot 9 \mathrm{H}_{2} \mathrm{O}, \mathrm{NaF}\right)$ and at various temperatures $\left(120{ }^{\circ} \mathrm{C}\right.$, $150{ }^{\circ} \mathrm{C}$, and $180{ }^{\circ} \mathrm{C}$ ) are also summarized in Table S2. $\dagger$ The detailed results indicated that undetected Al-leaching and low F-leaching concentrations were observed using the $\mathrm{Al}\left(\mathrm{NO}_{3}\right)_{3}$ $\cdot 9 \mathrm{H}_{2} \mathrm{O}$ and NaF mineralizers, respectively. Nevertheless, it is noted that fluoride $\left(\mathrm{F}^{-}\right)$contamination is also an endemic problem worldwide, therefore it is urgent and profound to improve and solve the trade-off between fluoride and arsenic contamination in subsequent studies. In summary, the leachability of $\mathrm{Al}, \mathrm{F}$, and $\mathrm{Si}$ from solid precipitates was related to the As-leachability, and a lower As-leaching concentration was observed with $\mathrm{Al}\left(\mathrm{NO}_{3}\right)_{3} \cdot 9 \mathrm{H}_{2} \mathrm{O}$ and $\mathrm{NaF}$ as mineralizers compared to with $\mathrm{Na}_{2} \mathrm{SiO}_{3} \cdot 9 \mathrm{H}_{2} \mathrm{O}$. It is speculated that interactions occur between scorodite and the mineralizers, meanwhile, the different interaction abilities between scorodite and the mineralizers were revealed by the different leaching concentrations for the different mineralization ions. Additionally, the scorodite incongruent dissolution process was proposed. As shown in ESI Table $\mathrm{S} 2, \dagger$ the total leaching concentration of arsenic ( $\sum$ As) was observed to exceed the total leaching concentration of iron $\left(\sum \mathrm{Fe}\right)$ in aqueous solution for the different solid samples, which means that the incongruent dissolution of scorodite can take place in the systems.

As shown in Table 1, the chemical composition of the scorodite solids at various temperatures and with various mineralizers was investigated. The detailed results indicated that the content of arsenic was roughly in accordance with the theoretical value (32 wt\%) in all cases, and it was indicated that the $\mathrm{Fe} /$ As molar ratio in the solid increased as the temperature increased with the different mineralizers. The incongruent dissolution of scorodite was responsible for this behaviour. ${ }^{35}$ The content of each of $\mathrm{F}, \mathrm{Na}, \mathrm{Al}$, and $\mathrm{Si}$ for the solid samples was also presented in Table $\mathrm{S} 2 . \dagger$ The detailed results indicated that a low content of the mineralization ion $(<3.0 \%)$ was present for the solid samples with various mineralizers and at various temperatures, and the chemical composition and mass balance were determined by the $\mathrm{Fe}$, As, and $\mathrm{O}$ elemental content. Additionally, as an auxiliary characterization method, EDS was used to analyze the particle composition of solid precipitate surfaces (Fig. S1 and Table S3†), and it was used to explore the relationship between the solid precipitate and the mineralizers.

As shown in Fig. 9 and Table $\mathrm{S} 4, \uparrow$ the change of arsenatebearing phases was investigated with various mineralizers and temperatures, and the detailed results indicated that three distinct phases, scorodite, ferric arsenate sub-hydrate (FAsH) and basic ferric arsenate sulfate (BFAS), were identified for the control group, $\mathrm{Na}_{2} \mathrm{SiO}_{3} \cdot 9 \mathrm{H}_{2} \mathrm{O}$-modified, $\mathrm{Al}\left(\mathrm{NO}_{3}\right)_{3} \cdot 9 \mathrm{H}_{2} \mathrm{O}$ modified, and NaF-modified solid samples at higher temperatures. The scorodite phase was mainly produced at $120^{\circ} \mathrm{C}$, and 
Table 1 Composition analysis for scorodite precipitates with various mineralizers $\left(\mathrm{H}_{2} \mathrm{O}\right.$-control experiment, $\mathrm{NaF}-\mathrm{modified}, \mathrm{Al}(\mathrm{NO})_{3} \cdot 9 \mathrm{H}_{2} \mathrm{O}-$ modified, and $\mathrm{Na}_{2} \mathrm{SiO}_{3} \cdot 9 \mathrm{H}_{2} \mathrm{O}$-modified) and temperature conditions $\left(120^{\circ} \mathrm{C}, 150{ }^{\circ} \mathrm{C}\right.$, and $\left.180{ }^{\circ} \mathrm{C}\right)$ for $25 \mathrm{~h}$ for the final mineralizer concentration of $0.02 \mathrm{M}$

\begin{tabular}{llllll}
\hline \multicolumn{5}{c}{ Mineralizer type $^{b}$} \\
\cline { 3 - 6 } Experimental group & $\mathrm{HMT}^{a}\left({ }^{\circ} \mathrm{C}\right)$ & $\mathrm{H}_{2} \mathrm{O}$-control experiment & NaF-modified & $\mathrm{Al}\left(\mathrm{NO}_{3}\right)_{3} \cdot 9 \mathrm{H}_{2} \mathrm{O}$-modified & $\mathrm{Na}_{2} \mathrm{SiO}_{3} \cdot 9 \mathrm{H}_{2} \mathrm{O}-\mathrm{modified}$ \\
\hline \multirow{2}{*}{ Arsenic content (\%) } & 120 & 28.42 & 31.61 & 26.86 & 28.54 \\
& 150 & 27.48 & 29.18 & 25.85 & 29.70 \\
Fe/As molar ratio & 180 & 24.76 & 27.53 & 27.20 & 28.63 \\
& 120 & 1.08 & 1.01 & 1.26 & 0.98 \\
& 150 & 1.28 & 1.09 & 1.62 & 1.08 \\
& 180 & 1.69 & 1.38 & 1.66 & 1.34
\end{tabular}

${ }^{a}$ HMT refers to the hydrothermal mineralization temperature $\left({ }^{\circ} \mathrm{C}\right) .{ }^{b}$ Mineralizer type refers to the different mineralizers that were used to improve the scorodite properties and then to determine the arsenic content (\%) and Fe/As molar ratio of solid scorodite precipitates.
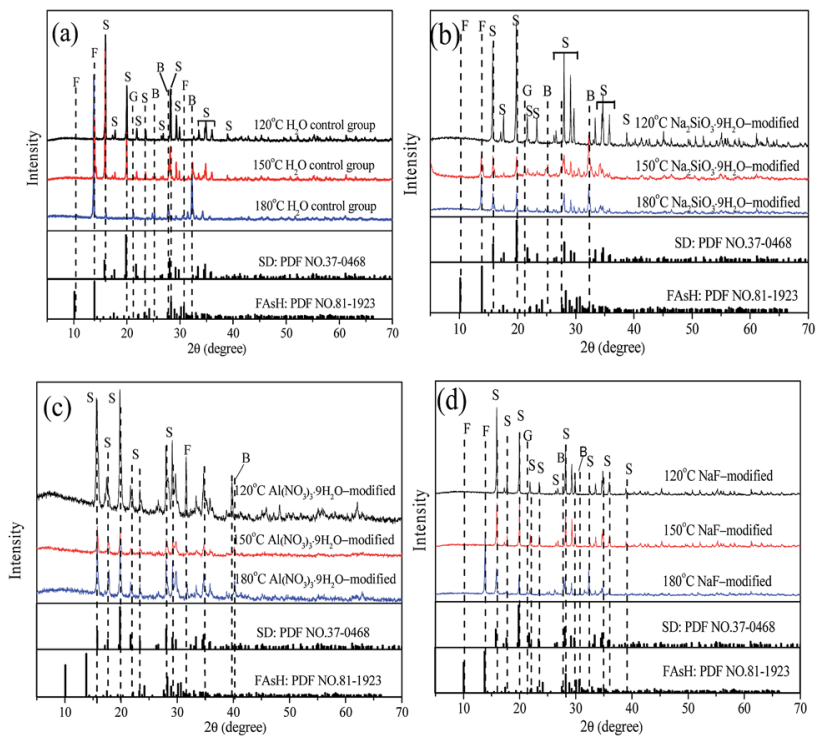

Fig. 9 XRD patterns for solid precipitates with various temperatures and the mineralizers (a) $\mathrm{H}_{2} \mathrm{O}$ control group, (b) $\mathrm{Na}_{2} \mathrm{SiO}_{3} \cdot 9 \mathrm{H}_{2} \mathrm{O}-$ modified, (c) $\mathrm{Al}\left(\mathrm{NO}_{3}\right)_{3} \cdot 9 \mathrm{H}_{2} \mathrm{O}$-modified, and (d) NaF-modified. "S" refers to the SD phase (scorodite); " $\mathrm{F}$ " refers to the $\mathrm{FAsH}$ phase $\left(\mathrm{FeAsO}_{4} \cdot 0.75 \mathrm{H}_{2} \mathrm{O}\right)$; " $\mathrm{G}$ " refers to the goethite phase; " $\mathrm{B}$ " refers to the BFAS phase $\left(\mathrm{Fe}\left(\mathrm{AsO}_{4}\right)_{1-x}\left(\mathrm{SO}_{4}\right)_{x}(\mathrm{OH})_{x} \cdot(1-x) \mathrm{H}_{2} \mathrm{O}\right)$. The standard XRD data can be seen in ref. 48 .

then the FAsH and BFAS phases appeared with an increase in temperature from $150{ }^{\circ} \mathrm{C}$ to $180{ }^{\circ} \mathrm{C}$. Precipitated goethite was also observed with an increase in temperature, the reasons for which are partly derived from the scorodite dissolution and ferric arsenate phases produced from sulfate media at high temperature. ${ }^{\mathbf{4 4 7}}$ Additionally, as shown in Table S5, $\dagger$ the semiquantitative quantification of how much of each phase (scorodite, FAsH, BFAS, and goethite) was present in the solid samples was achieved via JADE software. The detailed results indicated that the major arsenate-bearing phase of scorodite was produced at various temperatures and with various mineralizers, and small amounts of the arsenate-bearing phases, ferric arsenate sub-hydrate and basic ferric arsenate sulfate, were also observed. This may impact the stability of the solid samples. In our work, the detailed results indicated that a higher As-leaching concentration for the control group, $\mathrm{Na}_{2}$ $\mathrm{SiO}_{3} \cdot 9 \mathrm{H}_{2} \mathrm{O}$-modified, and $\mathrm{Al}\left(\mathrm{NO}_{3}\right)_{3} \cdot 9 \mathrm{H}_{2} \mathrm{O}$-modified solid samples was observed compared to that of the NaF-modified sample due to the differences in the FAsH phase content at $180{ }^{\circ} \mathrm{C}$. Gomez ${ }^{48}$ reported that short term leachability tests determined FAsH to be slightly more soluble than scorodite and BFAS.

The FT-IR spectra of a synthetic arsenate-containing solid after the hydrothermal mineralization with various mineralizers and at various temperatures are shown in Fig. 10. The vibration bands at $3518 \mathrm{~cm}^{-1}$ and $2994 \mathrm{~cm}^{-1}$ correspond to hydroxyl stretching vibrations from water molecules in scorodite, and the bending vibration of the water molecule is attributed to $1595 \mathrm{~cm}^{-1}$. Additionally, the vibration bands at $792 \mathrm{~cm}^{-1}$ and $899 \mathrm{~cm}^{-1}$ are assigned to As-O-Fe and As-O stretching
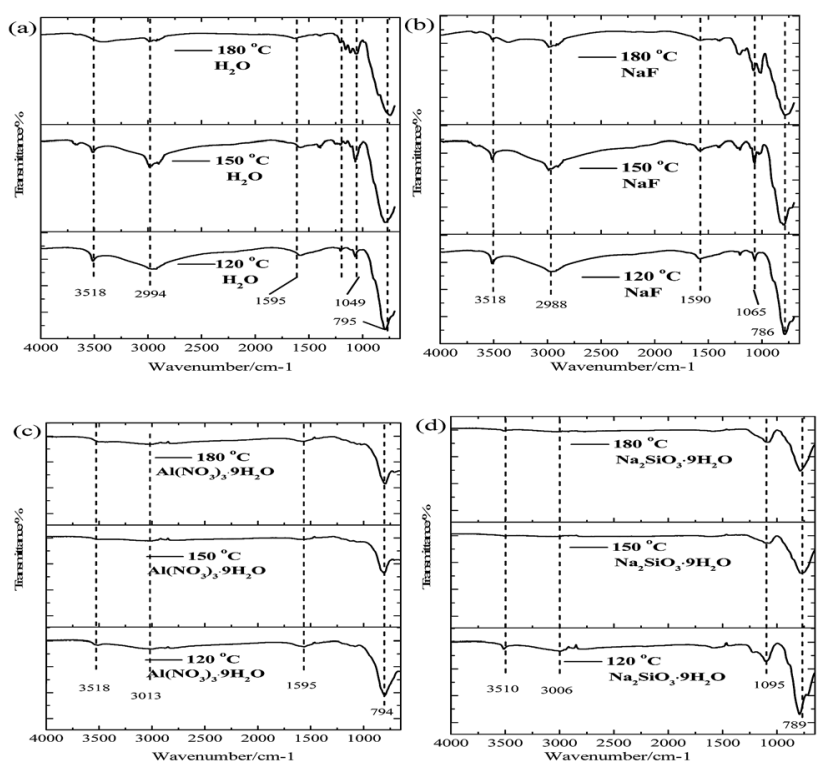

Fig. 10 FT-IR spectra of an arsenate-containing solid after hydrothermal mineralization with the various mineralizers (a) $\mathrm{H}_{2} \mathrm{O}$-control group, (b) NaF-modified, (c) $\mathrm{Al}\left(\mathrm{NO}_{3}\right)_{3} \cdot 9 \mathrm{H}_{2} \mathrm{O}$-modified, (d) and $\mathrm{Na}_{2}-$ $\mathrm{SiO}_{3} \cdot 9 \mathrm{H}_{2} \mathrm{O}$-modified, and at various hydrothermal mineralization temperatures $\left(120^{\circ} \mathrm{C}, 150^{\circ} \mathrm{C}\right.$, and $\left.180^{\circ} \mathrm{C}\right)$ for $25 \mathrm{~h}$. 


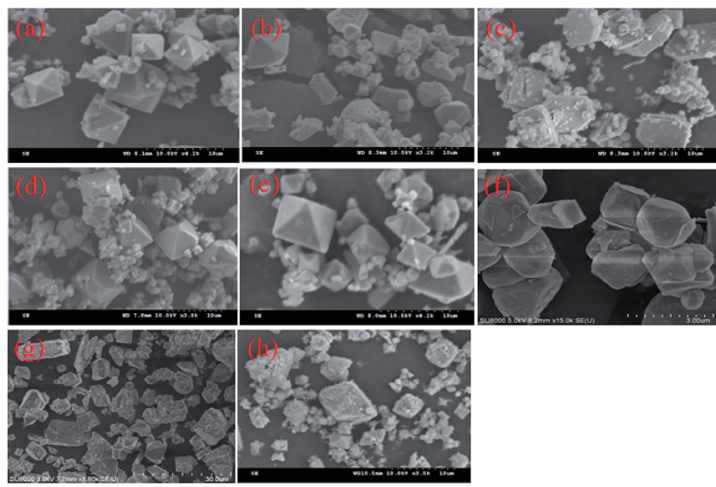

Fig. 11 SEM images for solid precipitates with various temperatures and mineralizers: (a) $120{ }^{\circ} \mathrm{C}-\mathrm{H}_{2} \mathrm{O}$ control group, (b) $150{ }^{\circ} \mathrm{C}-\mathrm{H}_{2} \mathrm{O}$ control group, (c) $180^{\circ} \mathrm{C}-\mathrm{H}_{2} \mathrm{O}$ control group, (d) $120^{\circ} \mathrm{C}-\mathrm{NaF}$ modified, (e) $150{ }^{\circ} \mathrm{C}-\mathrm{NaF}$ modified, (f) $180{ }^{\circ} \mathrm{C}-\mathrm{NaF}$ modified, (g) $180{ }^{\circ} \mathrm{C}-\mathrm{Na}_{2}-$ $\mathrm{SiO}_{3} \cdot 9 \mathrm{H}_{2} \mathrm{O}$ modified, and (h) $180{ }^{\circ} \mathrm{C}-\mathrm{Al}\left(\mathrm{NO}_{3}\right)_{3} \cdot 9 \mathrm{H}_{2} \mathrm{O}$ modified for $25 \mathrm{~h}$.

vibrations from the arsenate-containing solid, and new vibration bands at $1065 \mathrm{~cm}^{-1}$ may be derived from $\mathrm{SO}_{4}$ and/or $\mathrm{SiO}_{4}$ vibrations, which are related to the basic ferric arsenate sulfate phase. ${ }^{\mathbf{1 4 4 9}}$ For the control group (Fig. 10a), NaF-modified (Fig. 10b), and $\mathrm{Na}_{2} \mathrm{SiO}_{3} \cdot 9 \mathrm{H}_{2} \mathrm{O}$-modified (Fig. 10d), the intensity of the vibration bands at $3518 \mathrm{~cm}^{-1}$ and $2994 \mathrm{~cm}^{-1}$ decreased with the increase of mineralization temperature, which means that the hydroxyl content derived from crystal water molecules in the solid precipitates decreased. The main reasons for this were that the partial solid precipitates underwent a crystal phase transformation from the $\mathrm{FeAsO}_{4} \cdot \mathrm{H}_{2} \mathrm{O}$ structure to $\mathrm{FeAsO}_{4} \cdot 0.75 \mathrm{H}_{2} \mathrm{O}$, which was confirmed by the XRD spectra results (Fig. 9). Additionally, the intensity of the vibration bands at $1065 \mathrm{~cm}^{-1}$ increased for the control group and NaF-modified solid samples with an increase of the mineralization temperature from $120{ }^{\circ} \mathrm{C}$ to $180{ }^{\circ} \mathrm{C}$. This was derived from the formation of basic ferric arsenate sulfate crystal phase at various temperatures, and it was also confirmed by the XRD spectra results. For the $\mathrm{Na}_{2} \mathrm{SiO}_{3} \cdot 9 \mathrm{H}_{2} \mathrm{O}$-modified solid sample, the main vibration bands at $1095 \mathrm{~cm}^{-1}$ are assigned to $\mathrm{Si}-\mathrm{O}$ vibrations, which are closely related to the content of Si in the solid precipitates at various temperatures.

The morphological characterization of the scorodite was also investigated and the results are presented in Fig. 11. The results revealed that the crystal morphology evolved from octahedral to polygonal and finally to a hexagon lamellar structure with the control group as well as when $\mathrm{NaF}$ was added as a mineralizer. However, the morphology was anomalous and rough when $\mathrm{Na}_{2} \mathrm{SiO}_{3} \cdot 9 \mathrm{H}_{2} \mathrm{O}$ or $\mathrm{Al}\left(\mathrm{NO}_{3}\right)_{3} \cdot 9 \mathrm{H}_{2} \mathrm{O}$ was adopted as a mineralizer. Moreover, the particle size distribution of scorodite with various mineralizers and temperatures is displayed in Fig. 12. As shown in Fig. 12a-d, it was revealed that the curves were mainly dominated by two sizes of particle. The influence of various mineralizers on the RPS is shown in Fig. 12e. For NaF and $\mathrm{Na}_{2} \mathrm{SiO}_{3} \cdot 9 \mathrm{H}_{2} \mathrm{O}$ mineralizers, the RPS first increased and then decreased when the mineralization temperature increased from $120{ }^{\circ} \mathrm{C}$ to $180{ }^{\circ} \mathrm{C}$. Nevertheless, it was significantly higher than that of the control group. In contrast, for the $\mathrm{Al}\left(\mathrm{NO}_{3}\right)_{3} \cdot 9 \mathrm{H}_{2} \mathrm{O}$ mineralizer, the RPS gradually decreased with the increase of mineralization temperature from $120{ }^{\circ} \mathrm{C}$ to $180{ }^{\circ} \mathrm{C}$. The main reason was that adding mineralizers not only affects the solid precipitate phase structure, but also changes the distribution of RPS. The influence of mineralizers on arsenic leaching can be tentatively proposed to be as follows: the negative effect on leaching As-characteristics with $\mathrm{Na}_{2} \mathrm{SiO}_{3} \cdot 9 \mathrm{H}_{2} \mathrm{O}$ as a mineralizer can be claimed as a direct consequence of poor crystal morphology and the interaction between the $\mathrm{Na}_{2} \mathrm{SiO}_{3} \cdot 9 \mathrm{H}_{2} \mathrm{O}$ and scorodite through an "ion-exchange" or "metathetic" reaction and complexation reactions, and in particular, $\mathrm{Si}-\mathrm{O} \leftrightarrow \mathrm{As}-\mathrm{O}$ anion exchange might have taken place within the scorodite structure at least in the area near the surface, ${ }^{\mathbf{1 4 5 0}}$ even though it
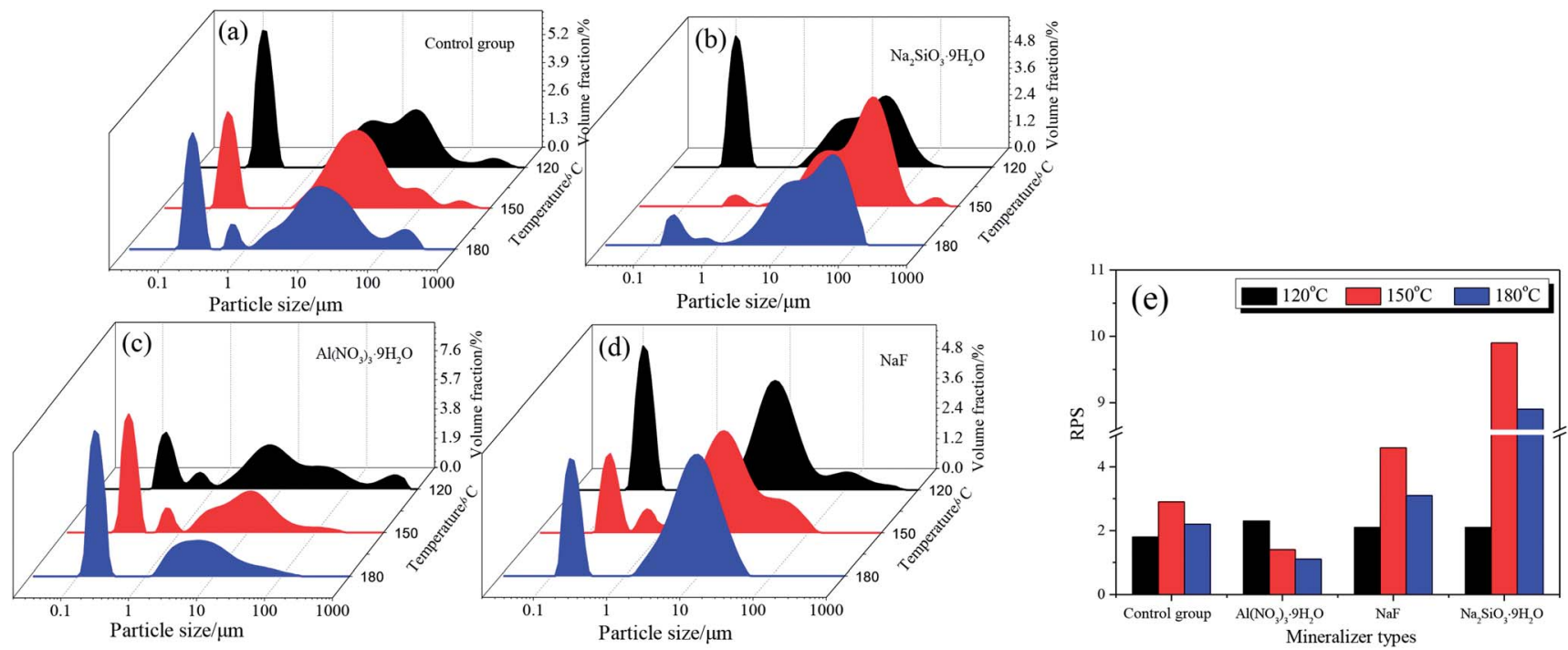

Fig. 12 The particle size distribution for solid precipitates under various temperature and mineralizers (a) $\mathrm{H}_{2} \mathrm{O}$ control group, (b) $\mathrm{Na}_{2} \mathrm{SiO}$. $9 \mathrm{H}_{2} \mathrm{O}$ modified, (c) $\mathrm{Al}\left(\mathrm{NO}_{3}\right)_{3} \cdot 9 \mathrm{H}_{2} \mathrm{O}$ modified, (d) $\mathrm{NaF}$ modified, and (e) RPS. 
possessed the largest RPS. When the mineralizer $\mathrm{Al}_{3} \mathrm{NO}_{3} \cdot 9 \mathrm{H}_{2} \mathrm{O}$ is added to the reaction system, small crystallite clusters of aluminum sulfate and/or bayerite may be formed in the scorodite surface, and these small crystallite clusters can influence the scorodite particle growth. ${ }^{51,52}$ Consequently, the RPS decreased with the increase of temperature, which gave rise to an increase in As-concentration. For the NaF mineralizer, which plays an important role in the morphology-orientation, the particle size control, and the modification of the growth of the scorodite crystal in the mineralization process, the scorodite stability was mainly affected by the grain size and crystal morphology, and adding mineralizers was conducive to improving RPS and crystal shapes and enhancing scorodite stability for $\mathrm{NaF}$, which leads to the lowest leaching Asconcentration being achieved at $150{ }^{\circ} \mathrm{C}$ because of the optimum size and crystal shapes. However, the scorodite crystal began to dissolve at high temperatures.

\subsection{The mechanisms influencing crystal growth and As- leachability}

The As-leachability was greatly influenced by the scorodite crystal characteristics and therefore this section proposes the mechanisms that were used to describe the scorodite crystal evolution process and As-leachability. As shown in Fig. 13, it was discussed from three aspects separately. Firstly, for the scorodite synthesis process, the crystal shape changes that the scorodite solids undergo, from a laminar structure to a polyhedron to a standard octahedral structure, were observed with an increase of the reaction time from $1 \mathrm{~h}$ to $5 \mathrm{~h}$. Meanwhile, the leached As-concentration decreased from $33.1 \mathrm{mg} \mathrm{L}^{-1}$ to $12.4 \mathrm{mg} \mathrm{L}^{-1}$. This process can be explained using crystallization thermodynamics theory. ${ }^{53}$ Initially, the surface nucleation process of the solute arsenic and iron species happened, and then the laminar scorodite crystal structure was formed. Subsequently, the scorodite crystal grows preferentially along the [001] direction, which leads to the formation of the polyhedron structure in the system environment. Finally, the orthorhombic structure of the octahedral shaped single crystals that are composed of almost (111) crystal planes was formed. Secondly, the aging and mineralization methods were designed to further analyze the As-leachability. The leached As-concentration significantly decreased from

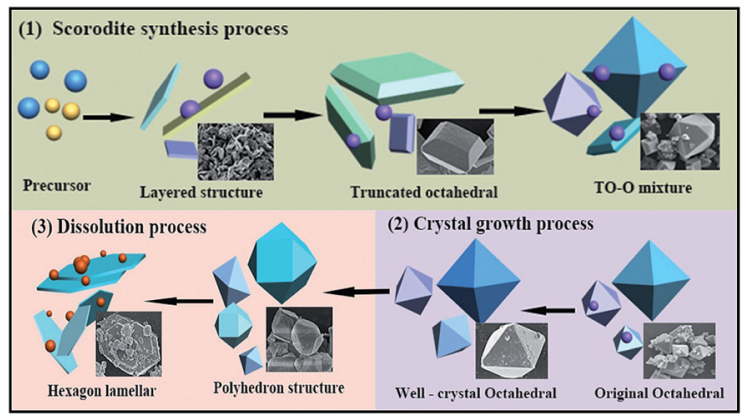

Fig. 13 Diagram of scorodite crystal behavior process.
$10.2 \mathrm{mg} \mathrm{L}^{-1}$ to $3.7 \mathrm{mg} \mathrm{L}^{-1}$ while the RPS increased from 1.50 to 2.64 because of the small crystalline grain dissolution and larger particle formation. This is conducive to increasing the crystal particle size and decreasing the As-leachability. The experimental tests indicated that the lowest leaching Asconcentration of $0.39 \mathrm{mg} \mathrm{L}^{-1}$ could be attained at $150{ }^{\circ} \mathrm{C}$ when $\mathrm{NaF}$ is employed as the mineralizer. In the third stage, the scorodite had begun to dissolve from the vertex of the octahedron to form polyhedron morphology. Microsphere particles and the approximate lamellar structure were observed when the hydrothermal temperature further increased, because scorodite [001] high-energy crystal faces are more easily dissolved than [111] planes..$^{54}$ In summary, it is essential to design the suitable hydrothermal system environment according to the scorodite crystal behavior process and As-leaching characteristics. It has a guiding significance for the disposal of arsenic-containing smelter wastewater and waste residue.

\section{Conclusions}

In summary, the mineralizer modified and tailored scorodite crystal characteristics and leachability for arsenic-rich smelter wastewater stabilization were investigated. It can be tentatively proposed that the arsenic leachability was mainly influenced by the crystal shapes and particle sizes. The crystal shape changes that the scorodite solids undergo during the aging period were observed, from a laminar structure to polyhedral to standard octahedral. Meanwhile, the leaching As-concentration can decrease gradually from $33.1 \mathrm{mg} \mathrm{L}^{-1}$ to $12.4 \mathrm{mg} \mathrm{L}^{-1}$. Additionally, the leached As-concentration can significantly decrease from $10.2 \mathrm{mg} \mathrm{L}^{-1}$ to $3.7 \mathrm{mg} \mathrm{L}^{-1}$ with an RPS increase from 1.50 to 2.64. The lowest leaching As-concentration of $0.39 \mathrm{mg} \mathrm{L}^{-1}$ could be attained when NaF is employed as the mineralizer. The scorodite crystal evolution process indicated that a suitable hydrothermal system is crucial for arsenic stabilization. This has a guiding significance for stable arsenic-containing smelter wastewater and waste residue.

\section{Conflicts of interest}

There are no conflicts to declare.

\section{Acknowledgements}

This work was supported by the National Natural Science Foundation (21577158, 21507148, and 21327011).

\section{References}

1 T. S. Singh and K. K. Pant, Solidification/stabilization of arsenic containing solid wastes using portland cement, fly ash and polymeric materials, J. Hazard. Mater., 2006, 131, 29-36.

2 M. Komárek, A. Vaněk and V. Ettler, Chemical stabilization of metals and arsenic in contaminated soils using oxides-A review, Environ. Pollut., 2013, 172, 9-22. 
3 A. Antemir, C. D. Hills, P. J. Carey, K. H. Gardner, E. R. Bates and A. K. Crumbie, Long-term performance of aged waste forms treated by stabilization/solidification, J. Hazard. Mater., 2010, 181, 65-73.

4 L. G. Twidwell, Environmental Considerations for Treatment of Effluent Waste Solutions and Solid Waste Products, in SME Mineral Processing and Extractive Metallurgy Handbook, 2019.

5 Y. In-Ho, M. Deokhyun, K. Kyoung-Woong, L. Keun-Young, L. Ji-Hoon and K. Mingyu, Mechanism for the stabilization/ solidification of arsenic-contaminated soils with Portland cement and cement kiln dust, J. Environ. Manage., 2010, 91, 2322-2328.

$6 \mathrm{~J}$. V. Bothe and P. W. Brown, Arsenic immobilization by calcium arsenate formation, Environ. Sci. Technol., 1999, 33, 3806-3811.

7 A. M. Nazari, R. Radzinski and A. Ghahreman, Review of arsenic metallurgy: Treatment of arsenical minerals and the immobilization of arsenic, Hydrometallurgy, 2017, 174, 258-281.

8 E. Arco-Lázaro, I. Agudo, R. Clemente and M. P. Bernal, Arsenic (V) adsorption-desorption in agricultural and mine soils: Effects of organic matter addition and phosphate competition, Environ. Pollut., 2016, 216, 71-79.

9 C. Jing, S. Liu and X. Meng, Arsenic remobilization in water treatment adsorbents under reducing conditions: Part I. Incubation study, Sci. Total Environ., 2008, 389, 188-194.

10 M. A. Ferguson, M. R. Hoffmann and J. G. Hering, $\mathrm{TiO}_{2}-$ photocatalyzed As(III) oxidation in aqueous suspensions: Reaction kinetics and effects of adsorption, Environ. Sci. Technol., 2005, 39, 1880-1886.

11 D. Ocinski, I. Jacukowicz-Sobala, P. Mazur, J. Raczyk and E. Kociołek-Balawejder, Water treatment residuals containing iron and manganese oxides for arsenic removal from water-characterization of physicochemical properties and adsorption studies, Chem. Eng. J., 2016, 294, 210-221.

$12 \mathrm{~S}$. Chatterjee and S. De, Adsorptive removal of arsenic from groundwater using chemically treated iron ore slime incorporated mixed matrix hollow fiber membrane, Sep. Purif. Technol., 2017, 179, 357-368.

13 S. Mou, A. Manna and P. Pal, Removal of arsenic from contaminated groundwater by membrane-integrated hybrid treatment system, J. Membr. Sci., 2010, 354, 108-113.

14 J. G. Adelman, S. Elouatik and G. P. Demopoulos, Investigation of sodium silicate-derived gels as encapsulants for hazardous materials-the case of scorodite, J. Hazard. Mater., 2015, 292, 108-117.

15 S. Bouzalakos, A. W. Dudeney and B. K. Chan, Leaching characteristics of encapsulated controlled low-strength materials containing arsenic-bearing waste precipitates from refractory gold bioleaching, J. Environ. Manage., 2016, 176, 86-100.

16 J. K. Shaw, S. Fathordoobadi, B. J. Zelinski, W. P. Ela and A. Z. Saez, Stabilization of arsenic-bearing solid residuals in polymeric matrices, J. Hazard. Mater., 2008, 152, 11151121.
17 K. Duquesne, S. Lebrun, C. Casiot, O. Bruneel, J. C. Personné, M. Leblanc, F. Elbaz-Poulichet, G. Morin and $\mathrm{V}$. Bonnefoy, Immobilization of arsenite and ferric iron by Acidithiobacillus ferrooxidans and its relevance to acid mine drainage, Appl. Environ. Microbiol., 2003, 69, 6165-6173.

18 C. Casiot, G. Morin, F. Juillot, O. Bruneel, J. C. Personné, M. Leblanc, K. Duquesne, V. Bonnefoy and F. ElbazPoulichet, Bacterial immobilization and oxidation of arsenic in acid mine drainage (Carnoulès creek,France), Water Res., 2003, 37, 2929-2936.

19 P. V. Nidheesh and T. S. A. Singh, Arsenic removal by electrocoagulation process: Recent trends and removal mechanism, Chemosphere, 2017, 181, 418-432.

$20 \mathrm{~J} . \quad$ F. Martínez-Villafañe, C. Montero-Ocampo and A. M. García-Lara, Energy and electrode consumption analysis of electrocoagulation for the removal of arsenic from underground water, J. Hazard. Mater., 2009, 172, 1617-1622.

21 T. Amalia, J. Ge and X. Meng, A comprehensive study of treatment of arsenic in water combining oxidation, coagulation, and filtration, J. Environ. Sci., 2015, 36, 178-180.

22 Y. Jia and G. P. Demopoulos, Coprecipitation of arsenate with iron (III) in aqueous sulfate media: effect of time, lime as base and co-ions on arsenic retention, Water Res., 2008, 42, 661-668.

23 T. M. Clancy, K. V. Snyder, R. Reddy, A. Lanzirotti, S. E. Amrose, L. Raskin and K. F. Hayes, Evaluating the cement stabilization of arsenic-bearing iron wastes from drinking water treatment, J. Hazard. Mater., 2015, 300, 522-529.

24 T. M. Clancy, K. F. Hayes and L. Raskin, Arsenic waste management: A critical review of testing and disposal of arsenic-bearing solid wastes generated during arsenic removal from drinking water, Environ. Sci. Technol., 2013, 47, 10799-10812.

25 G. Pokrovski, R. Gout, J. Schott, A. Zotov and J. C. Harrichoury, Thermodynamic properties and stoichiometry of As(III) hydroxide complexes at hydrothermal conditions, Geochem. Cosmochim. Acta, 1996, 60, 737-749.

26 D. K. Nordstrom and D. G. Archer, Arsenic thermodynamic data and environmental geochemistry, in Arsenic in ground water, ed. A. H. Welch and K. G. Stollenwerk, Kluwer Academic Publishers, Boston, Massachusetts, USA, 2003.

27 R. A. Jadhav and L. S. Fan, Capture of gas-phase arsenic oxide by lime: kinetic and mechanistic studies, Environ. Sci. Technol., 2001, 35, 794-799.

28 D. H. Moon, D. Dermatas and N. Menounou, Arsenic immobilization by calcium-arsenic precipitates in lime treated soils, Sci. Total Environ., 2004, 330, 171-185.

29 N. Martínez-Villegas, R. Briones-Gallardo, J. A. Ramos-Leal, M. Avalos-Borja, A. D. Castañón-Sandoval, E. Razo-Flores and M. Villalobos, Arsenic mobility controlled by solid calcium arsenates: A case study in Mexico showcasing a potentially widespread environmental problem, Environ. Pollut., 2013, 176, 114-122. 
30 P. Drahota and M. Filippi, Secondary arsenic minerals in the environment: A review, Environ. Int., 2009, 35, 1243-1255.

31 E. Krause and V. A. Ettel, Solubilities and stabilities of ferric arsenate compounds, Hydrometallurgy, 1989, 22, 311-337.

32 L. Haffert and D. Craw, Mineralogical controls on environmental mobility of arsenic from historic mine processing residues, New Zealand, Appl. Geochem., 2008, 23, 467-1483.

33 P. M. Swash and A. J. Monhemius, The characteristic of calcium arsenate compounds relevant to the disposal of arsenic from industrial processes, Mineral metals and the environment II, proceedings from IMM, 1996.

34 US EPA, Waste and Cleanup Risk Assess, Office of Solid Waste and Emergency Response, 1992.

35 M. A. Gomez, L. Becze, R. I. R. Blyth, J. N. Cutler and G. P. Demopoulos, Molecular and structural investigation of yukonite (synthetic \& natural) and its relation to arseniosiderite, Geochem. Cosmochim. Acta, 2010, 74, 58355851.

36 M.-C. Bluteau and P. G. Demopoulos, The incongruent dissolution of scorodite-solubility, kinetics and mechanism, Hydrometallurgy, 2007, 87, 163-177.

37 E. Krause and V. A. Ettel, Solubility and stability of scorodite, $\mathrm{FeAsO}_{4} \cdot 2 \mathrm{H}_{2} \mathrm{O}$ : new data and further discussion, Am. Mineral., 1988, 73, 850-854.

38 E. A. Rochette, G. C. Li and S. E. Fendorf, Stability of arsenate minerals in soil under biotically generated reducing conditions, Soil Sci. Soc. Am. J., 1998, 62, 1530-1537.

39 D. Langmuir, J. Mahoney and J. Rowson, Solubility products of amorphous ferric arsenate and crystalline scorodite $\left(\mathrm{FeAsO}_{4} \cdot 2 \mathrm{H}_{2} \mathrm{O}\right)$ and their application to arsenic behavior in buried mine tailings, Geochem. Cosmochim. Acta, 2006, 70, 2942-2956.

40 M. C. Harvey, M. E. Schreiber, J. D. Rimstidt and M. M. Griffith, Scorodite dissolution kinetics: implications for arsenic release, Environ. Sci. Technol., 2006, 40, 67096714.

41 Y. Kitamura, H. Okawa, T. Kato and K. Sugawara, Effect of ultrasound intensity on the size and morphology of synthesized scorodite particles, Adv. Powder Technol., 2016, 27, 891-897.

42 T. Fujita, R. Taguchi, M. Abumiya, M. Matsumoto, E. Shibata and T. Nakamura, Novel atmospheric scorodite synthesis by oxidation of ferrous sulfate solution. Part I, Hydrometallurgy, 2008, 90, 92-102.

43 L. G. Twidwell, Treatment of Arsenic-Bearing Minerals and Fixation of Recovered Arsenic Products: A Review, 2018, DOI: 10.13140/rg.2.2.12890.44486.
44 J. E. Dutrizac and J. L. Jambor, Characterization of the iron arsenate-sulphate compounds precipitated at elevated temperatures, Hydrometallurgy, 2007, 86, 147-163.

45 P. M. Swash and A. J. Monhemius, Hydrothermal precipitation from aqueous solutions containing iron (III), arsenate and sulphate. Hydrometallurgy, Chapman \& Hall, Cambridge, England, 1994, pp. 177-90.

46 M. A. Gomez, G. Ventruti, H. Assaaoudi, M. Ceklin, H. Putz and G. P. Demopoulos, The nature of synthetic Basic Ferric Arsenate Sulfate $\left(\mathrm{FeOHAsO} \mathrm{SO}_{4}\right)$ and Basic Ferric Sulfate $\left(\mathrm{FeOHSO}_{4}\right)$ : A crystallographic, molecular and electronic structure study with applications of their materials properties in energy and the environment, RSC Adv., 2013, 3, 16840-16849.

47 J. A. Strauss, V. Yahorava and M. A. Gomez, Pressure oxidation in gold circuits: Basic ferric arsenate sulphate and basic ferric sulphate behavior in downstream processing, in Proceedings World Gold and Nickel-Cobalt, Conference of Metallurgist, Canadian Institute of Mining, Metallurgy, and Petroleum, 2017, p. 13, ISBN 978-1-92687236-0, http://www.metsoc.org.

48 M. A. Gomez, L. Becze, J. N. Cutler and G. P. Demopoulos, Hydrothermal reaction chemistry and characterization of ferric arsenate phases precipitated from $\mathrm{Fe}_{2}\left(\mathrm{SO}_{4}\right)_{3}-\mathrm{As}_{2} \mathrm{O}_{5^{-}}$ $\mathrm{H}_{2} \mathrm{SO}_{4}$ solutions, Hydrometallurgy, 2011, 107, 74-90.

49 M. A. Gomez, H. Assaaoudi, L. Becze, J. N. Cutler and G. P. Demopoulos, Vibrational spectroscopy study of hydrothermally produced scorodite $\left(\mathrm{FeAsO}_{4} \cdot 2 \mathrm{H}_{2} \mathrm{O}\right)$, ferric arsenate sub-hydrate $\left(\mathrm{FAsH} ; \mathrm{FeAsO}_{4} \cdot 0.75 \mathrm{H}_{2} \mathrm{O}\right)$ and basic ferric arsenate sulphate (BFAS; $\mathrm{Fe}\left[\left(\mathrm{AsO}_{4}\right)_{1-\mathrm{x}}\left(\mathrm{SO}_{4}\right)_{\mathrm{x}}(\mathrm{OH})_{\mathrm{x}}\right]$. $\left.\mathrm{wH}_{2} \mathrm{O}\right)$, J. Raman spectrosc., 2010, 41, 212-221.

50 P. Singh, W. Zhang, D. M. Muir and R. G. Robins, The effect of silicate on the adsorption of arsenate on coprecipitated ferrihydrite, Can. J. Vet. Res., 2005, 71, 54-62.

51 K. Leetmaa, F. Guo, L. Becze, M. A. Gomez and G. P. Demopoulos, Stabilization of iron arsenate solids by encapsulation with aluminum hydroxyl gels, J. Chem. Technol. Biotechnol., 2016, 91, 408-415.

52 F. Lagno, S. D. Rocha, S. Chryssoulis and G. P. Demopoulos, Scorodite encapsulation by controlled deposition of aluminum phosphate coatings, J. Hazard. Mater., 2010, 181, 526-534.

53 J. A. Dirksen and T. A. Ring, Fundamentals of crystallization: Kinetic effects on particle size distributions and morphology, Chem. Eng. Sci., 1991, 46, 2389-2427.

54 J. W. Mullin, Crystallization, Butterworth-Heinemann, Oxford, 4th edn, 2001. 